\title{
A Liberdade de Expressão e o Direito de Crítica Pública
}

\author{
Por Bruno Nubens Barbosa Miragem \\ Mestrando em Direito Privado pela UFRGS \\ Professor da Instituição de Ensino Superior de Brasília - IESB \\ Professor (licenciado) das Faculdades Integradas Ritter dos \\ Reis, em Canoas/RS; \\ Ex-Professor Substituto de Direito Civil da UFRGS
}

Introdução; I - A liberdade de expressão como direito fundamental; A) Conteúdo e alcance da liberdade de expressão; B) Liberdade de expressão e pósmodernidade; II - O direito de crítica pública; A) Conteúdo e alcance do direito de crítica pública; B) Exercício do direito de crítica: limites e consequiência de sua violação; 1. Limites absolutos; 1.1. O princípio da não-discriminação; 1.2. O respeito ao Estado Democrático de Direito; 1.3. A promoção da paz social; 1.4. A integridade moral da pessoa; 2 . Limites relativos; 2.1 . Veracidade fática; 2.2 Relação de pertinência entre a crítica e os fatos; Considerações finais.

\section{Introdução}

A liberdade de expressão constitui, dentre os direitos-liberdades de matriz liberal, o que maiores divergências observa no que refere ao șeu conteúdo e alcance. Em geral, o ponto de discórdia por excelência é o que diz com os limites reconhecidos ao seu exercício. Mas a dificuldade de precisão desses limites não se caracteriza como algo necessariamente negativo. Ao contrário, revela a essência desse direito subjetivo de liberdade, cuja regra de autonomia do comportamento do titular que exerce o seu direito só pode ser limitada por uma razão de status fundamental semelhante ao que garante a juridicidade do direito cujo exercício se limita. 
Isaiah Berlin em seu famoso Four essays on liberty ${ }^{l}$, distinguiu o conceito de liberdade em liberdade negativa e liberdade positiva. A primeira, como espécie de liberdade em que o homem tem o poder de agir sem sofrer a obstrução dos outros ${ }^{2}$. Trata-se, como bem se sabe, da definição liberal de liberdade, cuja qualificação negativa restaria demonstrada pela negação da autoridade ${ }^{3}$. A liberdade positiva, de outra sorte, seria aquela que titularia o indivíduo, como ser humano racional, a ser conceber sua própria vontade, e de se auto-conduzir na concretização desta vontade ${ }^{4}$. Nesse sentido, seria o sujeito capaz de realizar seu desejo independente de condicionamentos externos que não devem, necessariamente, constituir uma interferência (o que seria impugnado pelo tradicional conceito de liberdade negativa), mas condicionamentos ou influências de caráter subjetivo. Trata-se do conceito de liberdade, pois, construído a partir do respeito à autonomia do indivíduo e seu poder de arbítrio, sua capacidade de fazer escolhas racionais.

A liberdade de expressão, assim, não seria mais do que o reconhecimento do direito do sujeito de projetar publicamente juízos que forma a partir do exercício da razão. Nesse sentido, aliás, é que fora concebido pelo pensamento liberal. Mas, para além disto, seria uma forma de reconhecer juridicamente a própria liberdade de pensamento. Afinal, qual a validade do pensamento se não pudesse o ser humano colocá-lo a prova expressando-o publicamente? Estaria se retirando a possibilidade de aferir sua exatidão, sua validade, pelo que a liberdade de pensamento não teria qualquer utilidade ${ }^{5}$. Nesse sentido a aguda observação de Hannah Arendt, para quem "a razão humana, por ser falivel, só pode funcionar se o homem pode fazer uso público dela" ${ }^{6 ”}$.

A liberdade de expressão, assim, acabou por se constituir num direito fundamental que, vinculado à liberdade de pensamento, permite não apenas a projeção pública de um sentimento ou juízo de valor sobre algo que se assenta na realidade fática, mas também a liberdade para o novo, o inédito, o diferente, que igualmente é produto da razão humana e não necessita guardar relação com a realidade imediata. $\mathrm{O}$ próprio conceito de liberdade artística ou liberdade de opinião podem se situar nesse plano. Não há necessidade da sensibilidade do artista concordar com um critério geral de beleza, assim como não há necessidade de que o juízo de valor que qualquer pessoa

\footnotetext{
1 Original editado por Oxford University Press, em 1969.

${ }^{2}$ Berlin, Isaiah. Quatro ensaios sobre a liberdade. Brasília: Editora da UnB, 1981, p. 136.

${ }^{3}$ Assim: Silva, José Afonso da. Curso de direito constitucional positivo. São Paulo: Malheiros, 2001, p. 235.

${ }^{4}$ Berlin, Isaiah, Quatro ensaios..., op, cit., p. 142 e ss.

${ }^{5}$ A proposição é de Kant, que relacionando ambas as liberdades, de expressão e de pensamento, acaba por vincular a primeira, de modo indissociável à idéia de autodeterminação do sujeito. Kant, Immanuel. A paz perpétua e outros opúsculos. Lisboa, 1988, p. 52. Apud: Miranda, Jorge. Manual de direito constitucional, t. IV. Coimbra: Coimbra Editora, 1998, p. 399.

${ }^{6}$ Arendt, Hannah. "Verdade e política". In: Entre o passado e o futuro. 5a ed. São Paulo: Perspectiva, 2000 , p. 291.
} 
forme a respeito da realidade seja conforme ao que consensualmente se entenda por correto.

Nesse ponto situa-se o que identificamos como o direito de crítica pública. Trata-se, essencialmente, de reconhecer-se ao ser humano o direito à discordância. $\mathrm{O}$ direito ao conflito de idéias, de posiçōes, sejam elas de qualquer natureza (política ou artística, por exemplo). Constitui-se, como veremos, em uma especialização do direito de livre expressão.

A utilidade de abordá-lo especificamente reside em determinar seu exato conteúdo, alcance e, conseqüentemente, os limites ao seu exercício. E daí investigar, afinal, as hipóteses em que se há de reconhecer seu exercício irregular através dos limites impostos pelo ordenamento jurídico.

\section{I - A liberdade de expressão como direito fundamental e suas conseqüências}

A liberdade de expressão vincula-se a outras tantas espécies de liberdades, como a liberdade de religião, a liberdade política, a liberdade de reunião e associação, e a de iniciativa econômica ${ }^{7}$. Trata-se, portanto, da liberdade do ser humano de projeção pública da sua vontade.

Concebida como um direito cujo exercício aproveitaria exclusivamente ao seu titular, recebe nova leitura a partir da Declaração Universal dos Direitos Humanos da ONU, de 1948, em que pela primeira vez é previsto o direito de receber informação e opiniâo $o^{8}$. A liberdade de expressão é observada então, pela primeira vez, como um direito que aproveita não apenas ao indivíduo, mas, sobretudo, à comunidade ${ }^{9}$.

Seu status de direito fundamental, de outra sorte, se origina da constatação do direito-liberdade de expressão como condição necessária à dignidade do homem, sendo previsto de modo expresso em praticamente todas as Constituiçóes ocidentais modernas. O alcance desta liberdade, assim como sua compreensão contemporânea é o que ora será examinado.

A) Conteúdo e alcance da liberdade de expressão

\footnotetext{
${ }^{7}$ Miranda, Jorge, Manual..., op. cit., p. 399.

${ }^{8}$ Assim o seu art. 19: "Todo individuo tem direito à liberdade de opinião e de expressão; esse direito inclui o de não ser molestado em razão de suas opiniões, o de investigar e receber informação e opiniōes e difundi-las, sem limitação de fronteiras, por qualquer meio de expressão".

${ }^{9}$ Nesse sentido veja-se: Saavedra Lopez, Modesto. La libertad de expresión en el estado de derecho. Entre la utopia y la realidad. Barcelona: Ariel Derecho, 1987, p. 67. Igualmente: Loretti, Damián M. El derecho a la información. Relación entre medios, público y periodistas. Buenos Aires: Paidós, 1995, p. 20.
} 
O conceito técnico-jurídico de liberdade de expressão se formou a partir de duas vertentes reconhecidas. De um lado o pensamento iluminista francês prérevolucionário, cuja essência propugnava a liberdade do indivíduo em relação ao Estado $^{10}$. Tendo em Montesquieu um dos mais relevantes pensadores, vai conceber a liberdade de expressão como espécie de garantia do controle do exercício do poder do Estado, a partir do pluralismo de associaçōes intermediárias e de vida coletiva descentralizada, a zelar pelo regular exercício do poder político ${ }^{11}$. A liberdade de expressão aparece pela primeira ve $z$ como instrumento de controle do poder ${ }^{12}$. Em segundo lugar, contribuiu decisivamente para a formação do conceito técnico-jurídico de liberdade de expressão, as conquistas da política inglesa a partir de Charles II, assegurando a liberdade e o fomento da atividade de imprensa como espaço do discurso público $^{13}$.

Concebido como direito subjetivo público, o direito-liberdade de expressão se classifica em distintos outros direitos subjetivos, conforme o seu modo de exercício. $\mathrm{O}$ mestre português Jorge Miranda, classificando a liberdade de comunicação social na Constituição portuguesa, a distingue em: (1) direitos individuais; (2) direitos institucionais; (3) direitos positivos e (4) os direitos de participação ${ }^{14}$. Diferenciam-se a partir da estrutura da relação em que se apresentam. Os primeiros de titulação individual, e oponíveis erga omnes (por exemplo, o direito de informar, acesso à informação e ser informado). Os direitos institucionais, que dizem com direitos de organismos não governamentais de se expressarem (o direito de acesso dos partidos políticos ao rádio e à televisão ${ }^{15}$ ou o livre exercício de culto religioso $\left.{ }^{16}\right)$. Os direitos positivos dizem com a faculdade do seu titular receber ou acessar informaçóes (direito de antena ${ }^{17}$ ou de publicar jorna ${ }^{18}$, por exemplo). E os direitos de participação os que garantem aos seus titulares a prerrogativa de efetivamente participarem da definição dos processos de produção e difusão da informação (no direito brasileiro, por exemplo, através do Conselho de Comunicação Social, previsto constitucionalmente ${ }^{19}$ ).

A liberdade de expressão, como direito subjetivo público genérico, de sua vez, é consagrada no direito brasileiro no art. $5^{\circ}$, incisos IV e IX da Constituição Federal de 1988. Em ambas as disposiçóes, a técnica constitucional é de amplitude da definição

\footnotetext{
${ }^{10}$ Veja-se: Comparatto, Fábio. Konder. A afirmação histórica dos direitos humanos. São Paulo: Saraiva, 2001 , p. 47.

11 De la Serna, Luis Escobar. Derecho de la información. Madrid: Dikinson, 1998, p. 31.

12 Nesse sentido: Von Hippel, Ernst. Historia de la filosofía política, t. II. Madrid, 1962, p. 88.

${ }^{13}$ De la Serna, Luis Escobar. Derecho..., p. 29. Igualmente, o excelente apanhado histórico de Lewis, Anthony. Make no law. New York: Random House Inc., 1991, p. 40 e ss.

${ }^{14}$ Miranda, Jorge. Manual..., op. cit., p. 405 e ss.

${ }^{15}$ Art. $17, \S 3^{\circ}$ da CF/88.

${ }^{16}$ Art. 50, VI da CF/88.

17 Art. 220, caput, e art.223 da CF/88.

${ }^{18}$ Art. 220, § 60 da CF/88.

${ }^{19}$ Art. 224 da CF/88.
} 
normativa (manifestação de pensamento; expressão de atividade intelectual, artística, científica e de comunicação), procurando pautar seu exercício a partir dos limites previstos em outras disposições, como, por exemplo, nos incisos $\mathrm{V} \mathrm{e} \mathrm{X} \mathrm{do} \mathrm{mesmo} \mathrm{artigo} 5^{\circ}$, que faz vizinho das disposições que consagram a liberdade de expressão, seus respectivos limites.

O alcance dos efeitos das normas jurídicas que consagram a liberdade de expressão, é notório, tem sua definição melhor indicada no campo teórico do que na prática. Os problemas práticos que se apresentam, no mais das vezes, referem ao suposto abuso - exercício irregular - da liberdade de expressão. $\mathrm{O}$ aspecto central da maioria dos litígios é da incompatibilidade do exercício da liberdade com o direito de integridade moral a partir da proteção da intimidade ou da honra do sujeito atingido. Todos direitos fundamentais (de mesmo status, portanto), quando do seu exercício verifica-se um conflito, a aplicação do direito ao caso deve buscar, necessariamente, sua compatibilidade.

A compreensão do conflito, contudo, invariavelmente parte do modo de exercício da liberdade de expressão, e por uma razão essencial: a liberdade é que se exerce de modo a projetar publicamente o produto da razão do titular do direito, divulgando versão sobre um fato ou formulando um juízo crítico sobre o mesmo. Tanto os direitos à intimidade e à vida privada, como o direito à honra, são direitos cujo modo normal de exercício é passivo, ou seja, não exige do seu titular uma atuação material de realização. Ao contrário, qualquer atuação material do titular é posterior a uma eventual violaçáo do seu direito, logo, caracteriza-se como resposta à eventual agressão. A mesma lógica observa-se em relação ao direito a honra, o qual se nota que o titular só atua materialmente com o fito de reparar o dano causado pela violação efetiva do seu direito ${ }^{20}$. Apenas quando o direito à liberdade de expressão não fora exercido, mas se conhece do modo como o será logo adiante, é que os titulares de direito à intimidade, à vida privada ou à honra poderão recorrer ao seu exercício antecipado, tendo em vista uma eventual violação posterior. Pode requerer, o titular do direito, a chamada tutela inibitória ${ }^{21}$. Entretanto sua atuação material limita-se a buscar, preventivamente, proteção concreta quanto a uma agressão potencial. $O$ que permite manter o reconhecimento do caráter passivo de exercício desses direitos.

Envolvida em conflito de direitos subjetivos, então, a técnica de ponderação haverá de iniciar pelo exame do modo de exercício da liberdade de expressão. Nesse

${ }^{20} \mathrm{O}$ direito de resposta ou mesmo o direito de ação exercido de modo a ter reconhecida pretensão de reparação do dano são atuações materiais posteriores.

${ }^{21}$ Sobre o tema, veja-se: Arenhart, Sérgio Cruz. Tutela inibitória da vida privada. São Paulo: RT, 2000 , em especial, p. 12 e ss. Igualmente, Torres, José Henrique Rodrigues. "A censura à imprensa e o controle jurisdicional da legalidade". In: Revista dos Tribunais, v. 705. São Paulo: Editora RT, julho de 1994, p. 30 e ss. 
sentido o abuso ou exercício irregular dela é que há de causar dano, não o contrário 22 . Os outros direitos subjetivos envolvidos são observados como limites da liberdade de expressão, embora não sejam vislumbrados pela doutrina e jurisprudência como direitos cujo exercício tenha a potencialidade de causar um dano - logo o direito a honra, a intimidade e a vida privada não sejam capazes, por si, de causar um dano pela sua característica de passividade.

A liberdade de expressão, desse modo, como direito fundamental, tem limitado seu exercício pela extensão que se vai reconhecer aos demais direitos fundamentais, determinando à técnica de ponderação determinar a extensão do exercício conforme a direito dos direitos em conflito.

B) Liberdade de expressão, honra e recato na pós-modernidade

A época em que vivemos é a época da incerteza. Incerteza esta que se caracteriza por ir além do temor que ordinariamente o homem guarda sobre o futuro. Ao mesmo tempo, trata-se de uma característica muito própria dos tempos atuais a necessidade de realização e reconhecimento de todo o êxito. $O$ ser humano precisa de algum modo mostrar-se ao mundo. Dada a perda de referências, de significados comuns, consensuais, qualquer espécie de realização assume sempre um caráter de parcialidade, de modo que o bastante se revista de uma vaga aspiração inatingível. A busca do bastante, nesse sentido, acaba por fazer o homem envolto em suas próprias aspirações e, necessariamente, frustraçōes. Esta situação determina a observação do outro como espécie de estranho, pela própria impossibilidade de obtenção de objetivos comuns fora da esfera pública. Como bem define Zygmunt Bauman, "nunca sabemos ao certo quando rir e quando chorar. E mal há um momento na vida, para se dizer sem escuras premoniçôes: "tive êxito"? .

\footnotetext{
${ }^{22}$ Assim por exemplo encontramos no excelente trabalho de Schmitt, Rosane Heineck. "Direito à informação - liberdade de imprensa x direito à privacidade". In: Sarlet, Ingo Wolfgang. A Constituição concretizada. Construindo pontes com o público e o privado. Porto Alegre: Livraria do Advogado Editora, 2000, p. 211: 241. A liberdade de imprensa, no caso, é que se limita, por seu modo de exercício ativo, não o contrário.

${ }^{23}$ Bauman, Zygmunt. O mal-estar da pós-modernidade. Rio de Janeiro: Jorge Zahar Editor, 1998, $p$. 111. Em sentido contrário, Sérgio Paulo Rouanet defende que embora exista uma consciência de ruptura esta não é real. Trata-se no seu entender, mais de um desejo de ruptura, após as guerras e tragédias creditadas à modernidade do que a efetiva ruptura pós-moderna. Nesse sentido, consciência e realidade não estariam convergentes. Rouanet, Sérgio Paulo. As razões do iluminismo. São Paulo: Companhia das Letras, 2000, p. 268 e ss. Em que pese os substantivos argumentos de Rouanet, o simples fato de encaminhar-se a sério uma discussão desse porte, assinala a perda de referências consensuais. Por trás da discussão sobre a realidade ou não do pós-moderno resplandece a dúvida sobre a vigência ou não dos paradigmas modernos, que sustenta a identificação da pós-modernidade.
} 
A falta de uma referência consensual faz com que busquemos expor nossas idéias, ou mesmo a falta delas ao público, buscando a conquista do outro não mais, exclusivamente, pelo argumento racional, mas por outros apelos quaisquer, como o visual, afetivo, caricato etc. Esta conquista do apreço comum passa a ser buscada pela simplificação do discurso público e exposição do que antes se confinava ao absoluto recato ${ }^{24}$.

É impossível dissociar a liberdade de expressão desse fenômeno. A multiplicação dos meios de comunicação em qualidade e quantidade foi determinante para o aumento assombroso do acesso à informação. Ao mesmo tempo, conhecidos os relatos da influência dos meios de comunicação na formação da compreensão comum sobre um determinado fato ${ }^{25}$.

Característica desta época, ainda, as facilidades de acesso a um número impressionante de informações sem que, todavia, em face à fatalidade do tempo não se possa tomar contato efetivo com mais do que ínfima parcela delas, sem qualquer idéia do que se deixou de conhecer. Eis mais um elemento de pontuação da desconstrução de verdades pós-moderna ${ }^{26}$.

No direito, a pós-modernidade se faz sentir por uma crise de legitimação ${ }^{27}$ caracterizada pelo questionamento de decisões legais ou jurisprudenciais, não lhe reconhecendo mais validade pela simples adequação formal do silogismo entre preceito e sanção, mas questionando do acerto das decisóes e sua capacidade de promover efetiva justiça. Nesse sentido, necessário se faz encontrar uma nova legitimação.

O ponto de convergência, assim, passa a ser o que Erik Jayme refere como o revival dos direitos humanos ${ }^{28}$. A narrativa principal em qualquer discurso público, em especial o discurso jurídico, passa a ter, nos dias de hoje, como eixo principal o respeito à dignidade da pessoa humana.

\footnotetext{
${ }^{24} \mathrm{O}$ exemplo notório, nesse aspecto, as relaçōes de afeição, conjugais ou não, que no passado eram intencionalmente confinadas quase que à exclusividade dos sujeitos envolvidos e que hoje surgem relatadas em detalhes nos diversos meios de comunicação, muitas vezes inclusive idealizadas artificialmente para cativar o público de forma mais efetiva.

${ }_{25}$ llustrativa a frase de um publicitário norte-americano citado por Haselden: "You can tell the ideals of a nation by its advertisements". Haselden, Kyle. Morality and the mass media. Nashville:Broadman Press, 1968, p. 152. No mesmo sentido, o estudo de Hans-Bernd Brosius e Dirk Engels, "Es possible que los medios de counicación influencien los demás, pero no logran hacerlo comigo. Las causas del efecto tercera persona". In:

Globalización, Democracia y medios de comunicación. Buenos Aires: Fund. Konrad Adenauer, 1999, p. 137.

${ }_{26}$ Marques, Cláudia Lima. "A crise científica do direito na pós-modernidade". In: Arquivos do Ministério da Justiça, no 50. Brasília: Ministério da Justiça, jan-jun/1998, p. 49.

${ }_{27}$ Marques, Cláudia Lima, op. cit., p. 52.

${ }^{28}$ Jayme, Erik. "Identité culturelle et integration: Le droit international privé postmoderne". In: Recueil des Cours de L'Academie de Droit International de la Haye, 1995, II, p. 36 e ss.
} 
Esse fato acaba por colocar um paradoxo. Observa-se, na verdade, um movimento em duas direções. De um lado a garantia da liberdade de expressão é condição de realização dos direitos humanos, pelo fato de que o direito-liberdade de expressão é um direito humano. Nesse sentido serve de garantia à efetividade de um dos mais significativos "direitos" ou aspiraçôes pós-modernas, que é o de respeito à diferença. Nesse sentido, respeitar o diferente estará vinculado necessariamente a garantia indiscriminada do discurso público, do pluralismo democrático ${ }^{29}$, o que juridicamente se titula pela liberdade de expressão.

De outro lado, assiste-se uma continua involução do indivíduo em direção de si mesmo e a proteção jurídica do privado em relação ao público. Partem do pressuposto da premência dos interesses do indivíduo, em razão da temporalidade da vida, que por vezes faz com os interesses individuais se choquem com o bem comum ${ }^{30}$. Nesse aspecto, o direito à informação como variante da liberdade de expressão se coloca com um caráter de complementaridade em relação ao direito à intimidade ${ }^{31} \mathrm{e}$ à honra.

Em relação à intimidade, a idéia do que se retira do discurso público - do âmbito comum, portanto, e se reserva ao privado. Esse se cerca de cautelas jurídicas diversas, tendo seu fundamento histórico no cristianismo e a noção de ato de bondade, em contraposição às noções de utilidade e excelência que presidia a avaliação dos atos humanos por gregos e romanos. A noção de ato de bondade, assim, é de que sua realização necessariamente se restringe do conhecimento ou divulgação ao público, uma vez que motivado pelo simples "amor à bondade 32 ". Desta origem se constrói a evolução do direito à intimidade até se determinar esta aspiração de reserva do íntimo como um direito subjetivo de personalidade do indivíduo, um direito de excluir do conhecimento de terceiros aquilo que diz respeito ao modo de ser da vida privada ${ }^{33}$. Ao mesmo tempo, a constatação de que a exposiçáo pública das informaçóes da intimidade, em regra, perde objetividade para converter-se na trivialidade do mexerico, banalizandoo público ${ }^{34}$.

\footnotetext{
${ }^{29}$ Assim Maria Cruz Llamazares Calazadilla, para quem a liberdade de expressão, a luz do direito espanhol, guarda fundamento em três instituições básicas do sistema jurídico, quais sejam, a dignidade da pessoa humana, a liberdade de consciência e o pluralismo político. Calazadilla, $M^{\mathrm{a}}$ Cruz Llamazares. Las libertades d expresión e información como garantia del pluralismo democrático. Madrid: Civitas, 1999, p. 48-49.

${ }^{30}$ A constatação é de Hannah Arendt, citada por Lafer, Celso. A reconstrução dos direitos humanos. Um diálogo com o pensamento de Hannah Arendt. São Paulo: Cia. das Letras, 2001, p. 237.

${ }^{31}$ Lafer, op. cit., p. 239-240.

${ }^{32}$ Lafer, op. cit., p. 263.

${ }^{33}$ Idem, p. 269.

34 Ibidem, p. 269.
} 
No mesmo sentido se observa o caráter da proteção do chamado direito à honra individual. Honra considerada como a própria projeção pública de determinados atributos inerentes ao indivíduo como socialmente dignos de apreço público. Direito à honra, como direito fundamental, o direito subjetivo oponível erga omnes de qualquer ser humano titular e ter reconhecido socialmente determinados atributos pessoais de caráter e personalidade ${ }^{35}$. O que a contrario sensu, realiza o comando proibitivo que se indique ao titular do direito atributos que não possui, expondo-lhe ao escárnio ou vexame público.

O direito subjetivo à honra pessoal assim realiza-se em duas direções. De um lado a proibição erga omnes (natureza negativa) de referência pública de quaisquer atributos de caráter ou personalidade do titular do direito, que não encontre suporte na realidade. De outro, a liberdade de ser titular e ser reconhecido pela comunidade (natureza positiva), através da projeção pública da sua personalidade, como detentor de determinados atributos de caráter, dos quais é efetivamente possuidor.

É importante esclarecer que quando se busca relacionar as novas interaçóes entre os direitos fundamentais de liberdade de expressão, intimidade e honra não são esses novidades pós-modernas. É notório o reconhecimento que o ser humano indica aos mesmos desde tempos imemoriais ${ }^{36}$. O que de algum modo é inovador é o status atual desses direitos, como condição de realização do indivíduo e sua articulação com o social através do reconhecimento jurídico do princípio da dignidade da pessoa humana como fundador da própria idéia de direito. E juridicamente derivados do princípio da dignidade humana, os direitos que ora referimos articulam-se atualmente, no plano dos direitos fundamentais, como direitos que necessitam ser coordenados, porque de igual status jurídico, faces de um mesmo anseio de realização da pessoa humana em todas as suas aspirações legítimas.

\section{II - O direito de crítica pública}

A articulação dos direitos oriundos da liberdade de expressão e o direito à honra e à intimidade apresentam questóes sensíveis quando defrontados com aspectos práticos do seu exercício. De relativa simplicidade a definição teórica de cada um desses direitos e as funções que assumem no ordenamento jurídico. Mais do que isso, a identificação de sua utilidade na realização do conceito mais geral indicado pela dignidade da pessoa humana é facilmente exposta pela fórmula de proteção da pessoa contra o arbítrio do Estado ou dos outros indivíduos.

\footnotetext{
${ }^{35}$ Para Beigner, honra seria "a estima e a glória que recebemos de nossos semelhantes". Beigner, Bernard. L'honneur et le droit. Paris: Librairie Générale de Droit et Jurisprudence, 1995, p. 39.

${ }^{36}$ Por exemplo; uma imagem clássica da história, dos cavalheiros resolvendo os litígios originados pelo desrespeito a sua honra através do duelo de armas, é de lembrança relativamente recente.
} 
Mais complexa, todavia, a coordenação desses direitos fundamentais distintos em questōes da realidade que, via de regra, deságuam nos tribunais em busca de um provimento jurisdicional específico. Os limites do exercício da liberdade de expressão foram respeitados ou não, afetando o direito à intimidade ou à honra de determinado indivíduo? Em que aspecto verifica-se a ultrapassagem dos limites do exercício da liberdade e a causa de danos a um indivíduo? São os problemas concretos que atestam ou não a praticidade das soluçôes teóricas propostas pelos juristas em geral.

Evidentemente que não se propõe o presente estudo a identificar o sem número de correlações possíveis entre a liberdade de expressão e outros direitos. Concentra-se, ao contrário, de uma especialização desse direito-liberdade cujo exercício é o que suscita talvez uma maior dificuldade de precisão quanto a sua regularidade. Trata-se do que ora se denomina direito de crítica pública, como espécie de direito à livre manifestação do pensamento, previsto no art. 5º, inciso IV da Constituição Federal de 1988, cujo exame se realiza em duas partes: a) a definição do seu conteúdo e alcance; e b) os limites ao seu exercício.

\section{A) Conteúdo e alcance do direito de crítica pública}

A liberdade de expressão, como já se referiu retro, tem relação imediata com a liberdade de pensamento e vice-versa. Não há livre pensar, sem livre expressar, pois sem esta se retira do indivíduo que pensa a possibilidade de conferir o acerto do seu pensamento. Logo, priva-se dele a própria liberdade de pensar, na medida que impossível verificar-se a correção do pensamento, logo sua validade substancial ${ }^{37}$.

O direito à informação tem seu caráter acentuado juridicamente a partir da Declaração Universal dos Direitos da Pessoa Humana, de 1948. Em seu art. 19, consagra a Declaração: “Todo indivíduo tem direito à liberdade de opinião e de expressão; esse direito inclui o de não ser molestado em razão de suas opiniōes, o de investigar e receber informação e opiniōes e difundi-las, sem limitação de fronteiras, por qualquer meio de expressão".

Fundamento da liberdade de expressão e sua previsão constitucional contemporânea, nos arts. $5^{\circ}$, incisos IV e IX e art. 220 da Constituição Federal de 1988, tem finalidades bem determinadas, das quais salientam-se duas: a) de realização do indivíduo livre para expressar seu pensamento e perceber o dos demais; b) controle e participação do poder político, institucionalizado ou não.

${ }_{37}^{37}$ Trata-se de um conceito kantiano, conforme demonstrado por Jorge Miranda, Manual..., op. cit., $p$. 399 (vide-se nota 4, retro). No mesmo sentido, Pinto Ferreira, para quem "a liberdade humana não se concretizaria na prática se não fosse dado ao homem o direito de liberdade de expressão. Essa liberdade abrange os direitos de manifestação da opinião, de discurso e de imprensa". Ferreira, Pinto. Curso de direito constitucional. São Paulo: Saraiva, 1988, p. 122. 
Em atenção a estas finalidades precípuas, duas as faculdades principais de intervenção no discurso público que se identificam contempladas pela liberdade de expressão. Primeiro, o direito de acesso e difusão da informação (faculdades de receber, investigar e difundir a informação ${ }^{38}$ ). Nesse caso, o conteúdo do direito está vinculado ao significado que se atribui ao termo informação. Podemos identificar dois significados para o termo informação.

$\mathrm{Na}$ doutrina tradicional, o termo informação está vinculado à idéia de verdade. Informar é divulgar uma verdade ${ }^{39}$. Nesse sentido, a liberdade de informar estaria vinculada à faculdade de investigar, receber ou difundir algo que guarde relação com a realidade dos fatos.

É certo de que a discussão do que seja verdade é algo cujas dificuldades extravasam aos limites desse trabalho. Hannah Arendt investigando as relações entre a verdade e a política, busca relativizar o próprio valor que indicamos a primeira. Em política, a mentira pode ser de utilidade, segundo demonstra, para por exemplo, evitar o recurso de meios violentos ${ }^{40}$.

Contudo, a idéia de verdade baseada em fatos difere substancialmente de um conceito de verdade filosófica ou científica, por exemplo. Enquanto esta obtém, em regra, o filósofo em seu isolamento, e partir de critérios próprios de transcendência. Já no que diz sobre a verdade baseada em fatos, Hannah Arendt identifica-a como necessariamente relacionada a outras pessoas. $\mathrm{Diz}$ respeito a eventos a um contexto próprio em que muitos estáo envolvidos, devendo o que se compreende por verdade ser estabelecido por testemunhas e dependente de comprovação. Sua existência, pois, ocorre somente em razão do que se fala dela ${ }^{41}$.

Nesse sentido, fatos e opinióes se colocam num mesmo plano, de modo que a verdade sobre fatos será baseada em relatos, e esses serão manifestados conforme as paixões e sensações do seu autor. Daí porque é possível crer que o conceito de verdade, na prática, conjuga-se de modo muito íntimo ao conceito de versão, qual seja o de narração sobre um determinado fato pretérito, ou de condiçóes e possibilidades de um fato futuro ${ }^{42}$. Nesse sentido, a verdade baseada em fatos é de natureza coerciva, à medida que percebida por todos. Segundo Hannah Arendt, além de acordo, disputa ou consentimento ${ }^{43}$.

\footnotetext{
${ }^{38}$ Assim, De la Serna, Luis Escobar, Derecho..., op. cit., p. 55.

${ }^{39}$ Nesse sentido Pilar Cousido, Derecho de la información (I). Madrid: Colex, 1992, p. 116-117. Apud: Castanho de Carvalho, Luis Gustavo Grandinetti. Liberdade de informação e o direito difuso à informação verdadeira. Rio de Janeiro: Renovar, 1994, p. 61.

${ }^{40}$ Arendt, Hannah. "Verdade e política", in: Entre o passado e o futuro., op. cit., p. 284.

${ }^{41}$ Arendt, Hannah, p. 295.

${ }^{42}$ A necessária constatação agora, de que ao narrar, o fazemos necessariamente em relação a um evento passado ou futuro, pela óbvia condiçāo de sujeito estranho ao objeto do evento.

${ }^{43}$ Arendt, Hannah, p. 297.
} 
Contudo, não se retira do termo informação um caráter convencional, qual seja de adequação da versão ao fato pretérito ou futuro. E nesse caso não se pode retirar o conteúdo arbitrário desta aferição.

A liberdade de informar, assim, estará vinculada à verdade baseada em fatos, e esta, por evidente, subordinada a uma relação de adequação, entre o conteúdo do relato indicado verdadeiro e o seu objeto. Hannah Arendt vai referir que a marca distintiva da verdade baseada em fatos consiste que o seu contrário não é o erro, a ilusão ou a opinião, mas a mentira, a falsidade deliberada ${ }^{44}$.

De qualquer modo, temos que a liberdade de informação que se reconhece no direito de receber, acessar e difundir informações, tem o limite do exercício destas faculdades jurídicas aferidas por uma relação de adequação entre a o conteúdo da informação e o evento a que ela se refere. Esta relação, de sua vez, deverá distinguir elementos essenciais e acessórios do conteúdo do relato, de modo eventualmente aferir in concreto, na hipótese de colisão do exercício da liberdade de informar com o direito à intimidade ou à honra, sobre o caráter escusável ou não ou náo da falta ou acréscimo, deliberado ou negligente, de uma determinada informação ${ }^{45}$.

A segunda faculdade de intervenção no discurso público trata-se do que se identifica por liberdade de manifestação de pensamento stricto sensu (em sentido lato estaria a abranger a própria liberdade de expressão, como afirmamos antes). Trata-se da faculdade jurídica de que são titulares todas as pessoas, de formularem juízos sobre fatos e fazê-los conhecer pelo público. Nesse sentido, não se submetem, a priori, à necessidade de adequaçáo com a verdade baseada em fatos, como no caso da liberdade de informação. É a forma de expressão, por excelência, das criações do espírito humano cuja vinculação com a realidade fática irá variar conforme o âmbito de projeção desta liberdade.

Uma espécie desta, cujos vínculos com a realidade fática são diminutos, é a liberdade de criação artística. Nenhum padrão ou paradigma de correção em relação à própria arte se poderá exigir do artista, pelo simples fato de que a obra artística, em essência se apresenta como manifestação da sensibilidade humana para o belo, cuja percepção é variável conforme o sujeito que percebe.

\footnotetext{
${ }^{44}$ Hannah Arendt, op. cit., p. 308.

Segundo indica a autora, o mentiroso é um homem de ação, dificilmente havendo uma figura política mais passivel de suspeição justificada do que o contador da verdade profissional que descobriu alguma feliz coincidência entre a verdade e o interesse (p. 309).

${ }^{45}$ Dentre as diversas técnicas judiciais de aferição da regularidade ou não do exercício de liberdade de informação, salientam-se a actual malice doctrine, da jurisprudência norte-americana, que buscando conferir maior extensão à liberdade de expressão prevista na Primeira Emenda à Constituição, reconhece a inescusabilidade da falha apenas quando da intenção deliberada do titular do direito em fazê-lo. Assim em Lewis, Anthony, Make no law, op. cit., p. 42.
} 
Assim também a liberdade científica cujos padrōes de correção são endógenos à própria ciência, sendo a eventual aceitação ou refutação da obra científica determinada a posteriori, pelas regras da ciência a que se destina, restando a liberdade de criar a obra científica intocada.

Submete-se a liberdade de manifestação do pensamento stricto sensu, em essência, apenas ao princípio da dignidade da pessoa humana que lhe serve ao mesmo tempo de razáo e de limite a sua existência. O ser humano, nesse sentido é livre para criar obras científicas, mas não para exercê-la de modo a dispor indistintamente da vida de seres humanos. Ao mesmo tempo, a liberdade artística e de iniciativa comercial facultam a promoção publicitária de produtos e serviços, desde que não estas não ofendam a comunidade ${ }^{46}$. As eventuais limitaçôes que se apresentam a quaisquer destas liberdades encontram seu fundamento, portanto, na proteção da dignidade da pessoa humana, seja tomada individualmente, seja nos seu significado cultural mais amplo ${ }^{47}$.

Esse direito subjetivo de livre manifestação do pensamento stricto sensu, ao mesmo tempo em que autoriza a projeção pública do pensamento, expóe a conseqüente exposição daquele que intervêm no discurso público à crítica dos demais indivíduos que tomam conhecem desta in tèrvenção.

O próprio conhecimento, já se observou, não se dissocia da exposição dialética de argumentos e contra-argumentos publicamente. Nesse sentido, observa-se como co-respectivo ao direito de projeção publica pelas diversas modalidades de expressão (os diversos modos de exercício da liberdade de expressão), o direito de crítica pública a esta intervenção. Esse direito subjetivo público, nuclear do princípio fundamental de garantia do pluralismo político constante do preâmbulo e do art. $1^{\circ}$, inciso IV, da Constituição Federal de 1988, é instrumental do próprio regime democrático conforme é comum observar nas mais distintas formas de defesa da liberdade de expressão ${ }^{48}$.

\footnotetext{
${ }^{46}$ A figura da publicidade abusiva, nas normas de proteção do consumidor. No Brasil, art. 37 , § 20 do Código de Defesa do Consumidor (Lei 8078/90). A respeito, veja-se por todos: Benjamin, Antônio Herman de Vasconcelos. Código Brasileiro e Defesa do Consumidor comentado pelos autores do anteprojeto. São Paulo: Forense Universitária, 1999, p. 296 e ss.

47 Aproveitamos o conceito de Ingo Wolfgang Sarlet qual seja o de dignidade da pessoa humana como "a qualidade intrínseca e distintiva de cada ser humano que o faz merecedor do mesmo respeito e consideração por parte do Estado e da comunidade, implicando, nesse sentido, um complexo de direitos e deveres fundamentais que assegurem a pessoa tanto contra todo e qualquer ato de cunho degradante e desumano, como venham a lhe garantir as condições existenciais mínimas para uma vida saudável, além de propiciar e promover sua participação ativa e co-responsável nos destinos da própria existência e da vida em comunhão com os demais seres humanos". Sarlet, Ingo Wolfgang. A dignidade da pessoa humana e os direitos fundamentais na Constituição Federal de 1988. Porto Alegre: Livraria do Advogado Editora, 2001, p. 60.

${ }^{48}$ A título de exemplo, a Carta de Princípios da Inter American Press Association, em que se consagra que "sem liberdade de imprensa não há democracia". Assim em: Torres, José Henrique Rodrigues..., "A censura à imprensa..., op. cit., p. 26.
} 
O direito de crítica pública se pode caracterizar então como o direito subjetivo público de formação e expressão de juízos críticos sobre pessoas, idéias, ações ou omissóes cujas circunstâncias em que se apresentem permitam inferir sobre o caráter público ou evidência social das mesmas. E não se resume àqueles cuja projeção se dá pela mera intervenção espontânea e episódica no discurso público, como a toda e qualquer pessoa ou grupo cujo destaque eventual ou permanente lhe determine um grau de evidência.

O direito de crítica, por si, é garantido legalmente como espécie de causa justificadora do exercício da liberdade de manifestação do pensamento, expressamente prevista no art. 27 da Lei 5.250/67 (Lei de Imprensa) que prevê em seu caput: "Não constituem abusos no exercício da liberdade de manifestação do pensamento e da informação" ${ }^{\prime \prime 9}$.

A) Exercício do direito de crítica: limites e conseqüência de sua violação

Alguns autores optam por adjetivar qual deva ser o conteúdo dos juízos críticos objeto do exercício do direito de crítica. Serrano Neves, por exemplo, indica que a crítica é apreciação construtiva, reparadora, analítica, corregedora, não a fazendo quem tem o mero prazer de contestar ${ }^{50}$. Não parece o direito de crítica submeter-se a limitaçōes a priori, como se entende da fixação de qualificações ao seu exercício. Ao contrário, é conteúdo lógico indissociável do direito de crítica pública, que eventual irregularidade do seu exercício só possa ser aferida posteriormente a sua realização, sob pena de censura ao pensamento e conseqüente violação do direito a pretexto de limitá-lo. Uma crítica política, por exemplo, poderá não ter qualquer objetivo senão o de desqualificar um determinado projeto político ou alguma proposta em específico. Não iria se tratar, na hipótese, de crítica parcial, mas de absoluta negação do valor da opinião adversária.

\footnotetext{
49 "Art . 27. Não constituem abusos no exercício da liberdade de manifestação do pensamento e de informaçāo: 1 - a opinião desfavorável da crítica, literária, artística, científica ou desportiva, salvo q uando inequivoca a intenção de injuriar ou difamar; II - a reproduçāo, integral ou resumida, desde que não constitua matéria reservada ou sigilosa, de relatórios, pareceres, decisões ou atos proferidos pelos órgāos competentes das Casas legislativas; III - noticiar ou comentar, resumida ou amplamente, projetos e atos do Poder Legislativo, bem como debates e críticas a seu respeito; IV - a reproduçã o integral, parcial ou abreviada, a notícia, crônica ou resenha dos debates escritos ou orais, perante juízes e tribunais, bem como a divulgação de despachos e sentenças e de tudo quanto for ordenado ou comunicado por autoridades judiciais; $V$ - a divulgação de articulados, quotas ou alegações produzidas em juizo pelas partes ou seus procuradores; VI - a divulgação, a discussão e a crítica de atos e decisões do Poder Executivo e seus agentes, desde que não se trate de matéria de natureza reservada ou sigilosa; VII - a crítica às leis e a demonstração de sua inconveniência ou inoportunidade; VIII - a crítica inspirada pelo interesse público; IX - a exposição de doutrina ou idéia. Parágrafo único. Nos casos dos incisos II a VI desse artigo, a reprodução ou noticiário que contenha injúria, calúnia ou difamação deixará de constituir abuso no exercício da liberdade de informação, se forem fiéis e feitas de modo que não demonstrem má-fé".

50 Serrano Neves, Francisco de Assis. Direito de imprensa. São Paulo: José Bushatsky Editora, 1977 , p. 368-369.
} 
Ao mesmo tempo, é intuitivo que o direito de crítica pública, embora seja faculdade jurídica cujo mérito reside proteção da racionalidade humana in abstracto, não está imune a limites de qualquer ordem. Pelo contrário, ao caracterizar seu exercício pela emissão de juízos críticos sobre um determinado objeto, a integridade desse objeto deverá ser preservada naquilo que não diz com o objeto da crítica ou dos limites jurídicos que se impõe para sua proteção contra a agressão ilegítima. Em uma fórmula simples, o titular do direito de critica não poderá exercê-lo de modo a negar validade a uma idéia de um indivíduo, utilizando como argumento determinada condição pessoal desse, que nenhuma relação observa com a idéia impugnada.

De outro modo, o exercício do direito de crítica pública pode se observar relativamente a uma idéia, ação ou omissão de titularidade difusa ou indefinida, e, contudo, ao impugná-la ou apoiá-la, o titular do direito acaba por ofender um determinado bem jurídico como, por exemplo, se observa da crítica genérica a um determinado grupo racial ou a valores socialmente assentes como corretos, cuja projeção pública de um juízo crítico contrário caracteriza uma agressão. É o exemplo da atribuição séria de determinada característica negativa à pessoa relacionando ou fundamentando esta em razão da opção sexual ou partidária da mesma. Não se observa relação lógica entre o conteúdo do juízo crítico e a característica apresentada como fundamento para ele, nem tampouco a ordem jurídica admite a utilização de argumentos relativos a discriminaçóes específicas ${ }^{51}$, em face do seu caráter ofensivo à dignidade da pessoa humana.

Os limites ao exercício do direito de crítica pública, assim, podem então ser divididos em dois grupos. De um lado, limites absolutos, de caráter geral, cujo fundamento se encontra na proteção da ordem pública com o significado contemporâneo que the indica a dignidade da pessoa humana. De outro, o que é identifica-se como limites relativos, indicativo de que se refere a limites específicos ao conteúdo da relação jurídica originada do exercício do direito de crítica pública.

\section{Limites absolutos}

Os limites absolutos ao exercício do direito de crítica pública são estranhos ao titular do direito, mas guardam o mesmo fundamento deste. Seu caráter absoluto deriva da característica fundamental da ordem jurídica e se apresenta vinculado, em distintos graus, ao princípio da dignidade da pessoa humana. Nesse sentido são limites revestidos do caráter de ordem pública, não podendo ser afastados inclusive pelo indivíduo

${ }^{51}$ Art. 3o, inciso IV da Constituição Federal de 1988. 
imediatamente afetado pelo conteúdo da crítica ${ }^{52}$. São limites absolutos ao exercício do direito de crítica pública: 1.1) o princípio da não-discriminação; 1.2. o respeito ao Estado Democrático de Direito; 1.3. a promoção da paz social; 1.4. a integridade moral da pessoa.

\subsection{O princípio da não discriminação.}

A Constituição Federal institui como objetivo fundamental da República Federativa do Brasil, em seu art. $3^{\circ}$, inciso IV "a promoçáo do bem de todos, sem preconceitos de origem, raça, sexo, cor, idade e quaisquer outras formas de discriminação"e em seu art. $5^{\circ}$, caput, que "todos são iguais perante a lei, sem distinção de qualquer natureza (...)", vedando o art. $5^{\circ}$ distinção de credo religioso (incisoVIII), trabalho (inciso XIII), e política, esta última em distintos momentos, como por exemplo o que determina a igualdade de participação política ("voto igual para todos", do art. 14) . Consagra assim o princípio da não-discriminação, na medida que não reconhece a legitimidade do estäbelecimento de diferenças entre os seres humanos manifestadas em razão de características específicas do indivíduo, e estabelecendo a competência legal para punição de eventual discriminação (art. $5^{\circ}$, inciso XLI). O direito de crítica pública, nesse sentir, não pode ser exercido de modo a expressar discriminação que a Constituição expressamente proíbe. Ao mesmo tempo, nota-se que a disposição constitucional abre a possibilidade do reconhecimento da proteção de outras espécies de discriminação não explicitadas no art. $3^{\circ}$. Nesse caso, a discriminação impugnada deverá sê-lo em razão da mesma essência das mencionadas em caráter exemplificativo no art. $3^{053}$, dizendo com o reconhecimento da dignidade humana como proteção da pessoa ${ }^{54}$.

\subsection{O respeito ao Estado Democrático de Direito.}

Outro limite duro ao exercício da crítica pública é o respeito ao Estado de Direito e aos valores democráticos. O fundamento lógico desta limitação é facilmente percebido, através da simples relação de causa e efeito. O direito de crítica pública é observado como especialização da liberdade de expressão. Nesse aspecto, sendo a liberdade de expressão garantida pela instituição de um Estado Democrático de Direito, não é admissível que o

\footnotetext{
52 Há um caso bastante conhecido, de uma liderança política que tendo sido desafiada por um militante adversário, insultou-o relativamente a sua raça e orientação partidária. Dias depois, o militante ofendido reconcilia-se com o ofensor, que inclusive dirige palavras de respeito e consideração sobre o ex-adversário. Por si só, a reconciliação da vítima imediata com o ofensor não logrou impugnar a responsabilidade do ofensor. A ofensa racista, nesse caso, embora realizada imediatamente a vítimas determinadas atinge a totalidade difusa dos indivíduos daquela mesma raça e, em última instância, a valores pertencentes a toda a humanidade, como o sentimento de igualdade de todos os seres humanos, independente de sua origem étnica.

${ }^{53}$ Segundo José Afonso da Silva, "a Constituição assim o faz porque essas razões preconceituosas são as que mais comumente se tomam como fundamento do discrime." Silva, José Afonso da. Curso de direito constitucional positivo, op. cit., p. 226.

${ }^{54}$ A respeito, veja-se: Bandeira de Mello, Celso Antônio. O conteúdo jurídico do princípio da igualdade. São Paulo: Malheiros, 1997, p. 24.
} 
seu exercício atente contra o próprio. Logicamente não deve a ordem jurídica de um Estado que garante a liberdade de expressão, e conseqüentemente o direito de crítica pública, reconhecer o exercício desta em prejuízo do próprio Estado e, em última análise do próprio direito de crítica, afetado pelo exercício que combate à manutenção do Estado Democrático de Direito.

Nesse sentido, é imperioso reconhecer que o respeito ao Estado Democrático de Direito, fundamento institucional da garantia de liberdade de expressão como limite do exercício do direito de crítica pública, não se confunde com quaisquer limites aos agentes públicos, titulares do poder político. A crítica ao chefe, ou a membros do poder político, jamais se caracteriza como crítica à instituição estatal. Ao contrário, por vezes estará inspirada na própria preservação de valores do Estado Democrático de Direito que estejam sendo desconsiderados pelo próprio agente público ${ }^{55}$.

Implícito também, no que diz com a preservação do Estado Democrático de Direito, a limitação do exercício de crítica pública que diga com a promoção do descumprimento da lei. Afora em circunstâncias excepcionais, em que a defesa do cumprimento de uma disposição legal possa significar ofensa aos princípios superiores que afirmam os próprios fins do Estado Democrático de Direito e o princípio da dignidade da pessoa humana (o que em regra legitimaria o exercício do direito à desobediência civil), a crítica da lei não pode conter comando ou sugestão para o seu não cumprimento. Tal manifestação, por si, caracterizaria a ofensa ao Estado Democrático de Direito, uma vez tendo sido a lei produzida de acordo com o procedimento legislativo previsto regularmente. Não se confunde direito de crítica à lei, de resto reconhecido pelo art. 17, III, da Lei no $5.250 / 67$, com a promoção do descumprimento da lei, esse recusado, salvo circunstâncias excepcionais já mencionadas, pelo respeito ao Estado Democrático de Direito.

\subsection{A promoção da paz social.}

O terceiro limite absoluto ao exercício do direito de crítica pública é o que se optou por denominar de promoção da paz social. A Constituição Federal de 1988 em seu preâmbulo

\footnotetext{
${ }_{55}$ Daí por exemplo a própria identificação de uma função social da imprensa, como instrumento de controle do poder político-administrativo e uma proteção contra o excesso de poder. Assim em José Afonso da Silva, op. cit., p. 250. Nesse sentido: Ap. Civ. 70000486878. 3o Grupo Cível. TJRS. Rel. Des. Clarindo Favretto. Julgado em 17.11.2000. "Responsabilidade civil da empresa jornalística. Abuso do exercício da liberdade de manifestação do pensamento não demonstrado. Artigo com conotação informativa e crítica, noticiando atos de improbidade realizados por agente político, movido por interesse eminentemente público. Art. 27, VII, exclui, expressamente, a imputação de abuso no exercício da liberdade de manifestação de pensamento e de informação, quando a crítica ou informação for inspirada pelo interesse público. Embargos acolhidos." Ainda: Ap. Cível 70000617340. 6a Câmara Cível. Rel. Des. Antônio Palmeiro da Fontoura. "Responsabilidade civil. Funcionário público. Liberdade de imprensa. Dano moral não caracterizado. Agravo retido. Preliminar de deserção do apelo. Não constitui abuso no exercício de liberdade de manifestação do pensamento, criticar os agentes ou servidores públicos, ou equiparados. Inteligência do art. 27 , VI, da Lei de imprensa. Preliminar rejeitada. Apelo improvido. Agravo retido prejudicado em virtude do improvimento da apelação".
} 
refere a harmonia social como fundamento do Estado brasileiro. Do mesmo modo, em seu art. $5^{\circ}$, caput, a inviolabilidade do direito à vida, à liberdade, à igualdade, à segurança e à propriedade. E no mesmo art. $5^{\circ}$, inciso III, consagra que ninguém será submetido a tortura nem a tratamento desumano ou degradante.

A opção evidenciada pelas diversas garantias determinadas ao longo do texto constitucional é pela não-violência, que, aliás, pontua o próprio sentido da existência do Estado e do atributo da segurança jurídica.

O direito de crítica pública, nesse sentir, não pode ser exercido de modo a incitar a violência, em contradição ao garantido pela Constituição. Note-se que a violência que ora se refere é a violência dos particulares, o exercício arbitrário das próprias razões. Não se confunde com a projeção pública, por exemplo, de propostas de atuação do poder de coerção do Estado. Assim, ultrapassa os limites de exercício do direito de crítica, aquele que defende publicamente um linchamento, por exemplo. Ao passo que não o faz aquele que defende um maior rigor na atuação do órgão policial no desempenho de suas atribuiçóes regulares.

A promoção da paz social é limite ao exercício do direito de crítica pública na proporção em que esse se dê a incentivar a substituição do Estado, detentor do monopólio da violência, por iniciativas particulares não autorizadas e que por isso, atentam contra o respeito ao poder estatal.

\subsection{A integridade moral da pessoa.}

Esse é talvez o limite ao exercício do direito de crítica pública de maior destaque prático na jurisprudência brasileira contemporânea. Trata-se de limitação do exercício do direito de crítica pública em favor da integridade moral da pessoa, reconhecidos juridicamente através dos direitos à honra e à intimidade e vida privada.

Submete-se à crítica pública o que se expóe no espaço público. A regra, assim, subsiste para indicar que aquilo que não se dispóe publicamente, características pessoais que se recobrem sob o manto da intimidade, ou comportamentais do sujeito, que não se expõe ao exame do público, não se submetem, pois, ao exercício de crítica pública. Ao mesmo tempo, a honra pessoal não cede ao exercício da crítica pública ${ }^{56}$.

\footnotetext{
${ }^{56}$ Ap. Cível 70001201532. 10 $0^{\text {a }}$ Câmara Cível. TJRS. Rel. Des. Luiz Ary Vessini de Lima. Julgado em 30.11.2000. "Responsabilidade civil. Crítica a ato judicial que atingiu a pessoa do magistrado. Liberdade de informação. Direito à honra e à imagem. A liberdade de imprensa encontra limites no próprio texto constitucional, que também resguarda, em cláusulas pétreas, os direitos individuais. A crítica a ato judicial, por outro lado, não pode atingir indevidamente a pessoa do magistrado, deliberando segundo sua consciência jurídica e livre convencimento, sendo-lhe vedado submeterse a qualquer outra influência, como eventual repercussão junto à mídia ou opiniāo pública, razão, aliás, da forma da sua investidura e das suas garantias que the são atribuídas pela sociedade através do poder constituinte originário. Dolo eventual. Assumir o risco equivale a querer. Lei de imprensa. Tarifaçāo. Inaplicabilidade. Indenização. Valor. Critérios. Improcedência em relação à coré que vai mantida. Apelação do autor parcialmente provida, improvendo-se a da ré".
} 
Intuitivo que, embora dotado de um alto nível de subjetividade, inerente a dimensão estritamente individual da moral, a honra pessoal, como limite à crítica pública não se pode vislumbrar como qualquer dissabor ou contrariedade causado pelo exercício do direito de crítica. Sobretudo porque, a rigor, conterá juízos negativos sobre aspectos do objeto da análise. Não há, pois, se falar em afetação moral pela mera discordância de opiniōes expostas no espaço público, assim como não se poderá traduzir em ofensa pessoal um juízo crítico em relação a comportamentos individuais que se projetem na esfera pública ${ }^{57}$. E isto pela simples razão de que a atuação pública, por si, submete o indivíduo à crítica pública. $O$ exemplo cabal, nesse sentido, é o do sujeito que exercendo direitos de participação política - seja ocupando funçóes públicas, seja intervindo no debate público sobre uma determinada questão-submete-se ao exercício do direito de crítica pública por qualquer dos membros da comunidade.

O exame in concreto desse limite absoluto do exercício do direito de crítica pública deve se estabelecer sob dois ângulos. De um lado, à consideração do próprio conceito de honra pessoal antes mencionado, que expressa a prerrogativa do sujeito, de ter projetado, publicamente, qualidades pessoais de caráter que efetivamente possui. Se o conteúdo da crítica é a negação de uma qualidade pessoal alegada como possuída, o exame do regular exercício do direito se restringe à identificaçáo ou náo da posse desta qualidade e, de outro lado, do caráter do qual esta se reveste, se público ou privado. Ou seja, se estará ou não sob o manto da intimidade ou da vida privada do indivíduo.

\section{Limites relativos.}

Os limites relativos são limites que dizem com a relação que se produz pelo exercício do direito de crítica pública. Pontuam critérios a serem observados pelo exercício desse direito de crítica, identificados na relação entre a crítica e o seu objeto, de modo a garantir,

\footnotetext{
57 INQO 503/RJ. STF. Rel. Min. Sepúlveda Pertence. DJU 26.03.93. "1. Ação penal originária: Re-ratificação da denúncia: caso de admissibilidade e de admitir-se a re-ratificação da denúncia no processo da ação penal da competência originária, que se faz antes da decisão plenária sobre o seu recebimento e apenas para corrigir erro material na transcrição de uma das frases tidas por ofensivas e imputadas ao denunciado. 2. Imunidade parlamentar material: não incidência. Ainda quando se admita, em casos excepcionais que o congressista, embora licenciado, continue projetado pela imunidade material contra a incriminação de declaraçōes relativas ao exercício do mandato, a garantia não exclui a criminalidade de ofensas a terceiro, em atos de propaganda eleitoral fora do exercício da função e sem conexão com ela (Cf.INQ 390, 27.9.89, Pertence RTJ 129/970). 3. Crime contra a honra e discussão político-eleitoral: limites da tolerância. As discussões políticas particularmente as que se travam no calor das campanhas eleitorais renhidas, são inseparáveis da necessidade de emissão de juízos necessariamente subjetivos sobre qualidades e defeitos dos homens públicos nelas diretamente envolvidos, impondo critério de especial tolerância na sua valoração penal, de modo a não tolher a liberdade de crítica que os deve proteger, mas a tolerância há de ser menor, quando ainda que situado no campo da vida pública ou da vida privada de relevância pública do militante político. O libel do adversário ultrapassa a linha dos juízos desprimorosos para a imputação de fatos mais ou menos concretos, sobretudo, se invadem ou tangenciam a esfera da criminalidade. Conseqüente viabilidade da denúncia no caso concreto. Que se recebe".
} 
de um lado, a dignidade da pessoa humana do sujeito cuja atuação própria ou produto dela, estejam sob crítica e de outro o direito à informação verdadeira.

São dois os limites relativos ao exercício do direito de crítica: 2.1. Veracidade fática; 2.2. relação de pertinência fática da crítica.

\subsection{Veracidade fática.}

Já se discorreu, quando se tratou da liberdade de informação, das dificuldades de precisão do que seja verdade baseada em fatos. Em grande medida, afirma Hannah Arendt que a determinação da verdade baseada em fatos e a liberdade de opinião se identificam ${ }^{58}$. Nesse sentido as dificuldades da determinação da verdade baseada em fatos devem ser consideradas na determinação desse limite relativo.

A veracidade fática como limite ao exercício do direito de crítica deve ser observada nesses limites inerentes a sua própria determinação. Nesse sentido o que se constitui limite não é a correção ou incorreção da crítica, a qual por essência não se submete a um controle jurídico de correção ou incorreção ${ }^{59}$. De se considerar, pois, que o direito de crítica pública engloba, inclusive, o direito de fazer uma crítica errada ou equivocada, não havendo se falar por isso em exercício irregular do direito.

O limite da veracidade fática, nesse aspecto, deve ser observado de modo estrito, na relação entre o conteúdo da crítica e seu objeto, como necessidade de adequação das premissas à conclusão. Se a crítica se refere a um ato $x$, é preciso que esse ato $x$ tenha existência ${ }^{60}$. Em tal não ocorrendo, a crítica é infundada, e o exercício do direito irregular. Contudo, não é qualquer erro quanto aos fatos que acaba por caracterizar o limite ao direito de crítica. Afinal, em se tratando do âmbito de maior liberdade da

\footnotetext{
${ }^{58}$ Hannah Arendt. "Verdade e política". In: Entre o passado..., op. cit., p. 285.

${ }^{59}$ HC 16982/RJ. STJ. Rel. Min. Félix Fischer. DJU 29.10.91, p. 229. "Penal e Processual Penal. Habeas corpus. Crime de imprensa. Crítica e ofensa. Liberdade de imprensa. Ausência de justa causa (Art. 648, inciso I, do CPP). I - Observações críticas, ainda que irritantes, nos limites da divulgação da situação fática, não configuram, de per si, crime de imprensa (art. 27, inciso VIII da Lei de Imprensa). II - Não se pode alçar à condição de ilícito penal aquilo que somente é desejado pela especial susceptibilidade da pessoa atingida e nem se deve confundir ofensa àhonra, que exige dolo e propósito de ofender, com crítica jornalística objetiva, limitada ao animus criticandi ou ao animus narrandi, tudo isto, sob pena de cercear-se a indispensável atividade da imprensa. III - "A relação entre lei e liberdade é, obviamente, muito estreita, uma vez que a lei pode ou ser usada como instrumento de tirania, como ocorreu com freqüência em muitas épocas e sociedades, ou ser empregada como um meio de pôr em vigor aquelas liberdades básicas que, numa sociedade democrática, são consideradas parte essencial de uma vida adequada." (DENNIS LLOYD). Writ concedido, trancando-se a ação penal".

${ }^{60} \mathrm{O}$ que é reconhecido juridicamente pelo direito à informação verdadeira, da qual refere Castanho de Carvalho, Luis Gustavo G. Liberdade de informação..., op. cit., p. 56.
} 
vontade humana, no caso do discurso público apenas o erro caracterizado como falsidade deliberada é que poderá ser indicado como irregularidade do exercício do direito ${ }^{61}$.

No mesmo sentido, se o exercício do direito de crítica pública envolve o cometimento de um ato criminoso, necessariamente a ocorrência do crime e a determinação da sua responsabilidade devem estar comprovadas, sob pena de violação à presunção de inocência com sede constitucional (art. $5^{\circ}$, inciso LVII $)^{62}$. Nesse caso, o direito à informação suporta distinta articulação desse limite, mais flexível, porquanto relativo ao exercício da liberdade de informar o público sobre a ocorrência de um evento a ser noticiado (dado objetivo), e as pessoas envolvidas nele (dado subjetivo) sobre o que recai a reserva da presunção da inocência. Portanto sua consideração, no máximo, poderá se dar como hipótese.

O exercício do direito de crítica pública, nesse prisma, só pode se dar em relação a fatos verdadeiros (verdade baseada em fatos). Ou ainda hipóteses de fato, cuja conclusão não seja demonstrada como definitiva, caracterizando o caráter precário das afirmaçóes não comprovadas e as conclusões que delas advêm.

\subsection{Relação de pertinência fática da crítica.}

O segundo limite relativo, a ser examinado a partir da relação do conteúdo da crítica e o objeto sob exame. É a relação de pertinência fática entre o exercício do direito de crítica pública e a atuação humana criticada. Nesse sentido, lembre-se da relação lógica necessária entre premissa menor e premissa maior, entre a realidade fática que sustenta a afirmação e o juízo crítico que se realiza em face à realidade. Assim, inadequação da crítica apenas se poderá exigir, se esta se apoiar em fatos não verdadeiros.

\footnotetext{
${ }^{61}$ Assim: Inq. 132/SP. STF, Rel. Min. Néri da Silveira. DJU 28.09.01, p. 38. "Inquérito. Queixa. 2. Vereador querelado. Emenda Constitucional $n^{o}$ 1/1969. 3. Alegação de difamação e injúria. 4. Discursos proferidos no recinto da Câmara de Vereadores, tecendo críticas quanto a atos administrativos do Governo municipal. 5. Defesa do querelado alegando não ter havido intenção de ofender o querelante, mas, apenas, criticar, no exercício do mandato de vereador, atos da Administração, que o querelado considerava errados e inconvenientes aos interesses do povo. 6 . Exame da prova que leva a não se ter como caracterizada a intenção de difamar ou injuriar. 7. Extinção da punibilidade pela prescrição da pretensão punitiva, quanto ao delito de injúria. 8 . Rejeição da queixa, relativamente ao crime de difamação".

62 Assim, Ap. Civ. 70000860312. 9a Câmara Cível. TJRS. Rel. Des. Mara Larsen Checi. "Responsabilidade Civil. Órgão de imprensa. Publicação de fato-crime não verdadeiro. Dano moral configurado. A violação à direito de personalidade, causada por abuso no exercício da liberdade de expressão e informação, através da divulgação da prática de fato criminoso, sem correspondência com a verdade, gera o dever de reparar o dano moral correspondente. Inteligência do art. 49 da Lei $n^{\circ}$ 5.250/67. Indenização. Imprensa. Arbitramento. Critérios. A Carta Magna de 1988 veio suplantar, através do seu art. 5o, inc. $X$, as barreiras tarifárias estabelecidas na chamada lei de imprensa, restando confiada ao prudente arbítrio do juiz a estimativa do valor da reparação. Sentença reformada em parte".
} 
Contudo, tal qual referiu-se quanto ao limite da veracidade fática, não há se falar em falsidade em razão de mera divergência de interpretação da realidade. Do que se trata nesse caso, é de crítica fundada em falsidade deliberada ou culposa do crítico, o que se deverá apurar no caso concreto. A culpa, de sua vez, prevalece através da caracterizaçăo da falta aos cuidados de prudência, diligência e os conhecimentos técnicos, se exigíveis (como no caso do profissional jornalista) de quem produz a informação ${ }^{63}$.

O mero exercício do direito de crítica, nesse sentir, não se coloca, em nenhum momento sob o crivo de correção ou não, o que seria restrição inadmissível - como já dissemos - ao exercício do direito de crítica pública.

Esta relação de pertinência fática, do mesmo modo, determina que o conteúdo da crítica não supere o seu objeto concreto, qual seja, uma atuação humana material avançando, por exemplo, para ofensas pessoais ou fatos que não tenha relação com o objeto imediato do juízo formulado.

\section{Consideraçōes finais}

Assim, o direito de crítica pública é um direito subjetivo público, especialização da liberdade de expressão constitucionalmente prevista, cujo conteúdo diz respeito à livre manifestação do pensamento através da produção intelectual de juízos críticos da realidade.

Não se submete a limites estritos como o exercício da liberdade de informação. Nesse sentido, não está inadvertidamente sob o crivo de correção da verdade baseada em fatos a que se submete a informação. Como expressão da liberdade criativa e racional do ser humano, o direito de crítica pública tem seus limites inspirados no fundamento do próprio regime de liberdades e seu princípio conformador, da dignidade da pessoa humana (limites absolutos). E também em relação de adequação do exercício do direito de crítica e a realidade fática submetida a esta (limites relativos).

\footnotetext{
${ }^{63}$ Nesse sentido: Ap. Civ. 70000631119. 5a Câmara Cível. TJRS. Rel. Des. Clarindo Favretto. "Responsabilidade civil da empresa jornalística. Abuso no exercício da liberdade de manifestação de pensamento nã demonstrado. Artigo com conotação informativa e crítica, denunciando falta de decoro parlamentar, movido por interesse eminentemente público. Art. 27, VII, Lei 5250/67 - Lei de imprensa. A lei $n^{\circ} 5250$, ex vi do seu artigo 27 , VII, exclui, expressamente, a imputação de abuso no exercício da liberdade de manifestação do pensamento e de informaçāo, quando a crítica ou informação for inspirada pelo interesse público. Sentença confirmada".
} 
Quanto aos limites relativos, observe-se, não estão dispostos como relação de correção ou adequação do conteúdo da crítica, senão do seu pressuposto fático, estabelecendo estrita proteção contra a falsidade deliberada ou culposa. E culpa, nesse sentido, como a falta e um dever pré-determinado, que não pode ser formulado a posteriori, já havendo o conhecimento do conteúdo da crítica e de eventual discordância quanto ao mérito da mesma.

Como manifestação da liberdade de expressão e do significado que esta encerra, o direito de crítica pública não se submete ao exame de mérito sobre o conteúdo do seu exercício - o que de resto é inexigível sob pena do próprio sacrifício do direito. Assim, a análise da regularidade do seu exercício deverá ser obtida a partir dos elementos caracterizados como seus limites absolutos ou relativos, jamais em relação à concordância ou divergência do resultado material do juízo crítico formulado. 